\title{
Tidal Energy Utilization of Larantuka Strait by Dual Tidal Turbines to Increase National Energy Resilience
}

\author{
Eko Soejianto $^{*}$, Khansa Hanifa Zahra* ${ }^{* *}$, Suci Nur Hidayah ${ }^{* * *}$ \\ Petroleum Engineering Department, Faculty of Technology Mineral, UPN Veteran Yogyakarta \\ Jl. SWK 104, Condongcatur, Depok, Sleman, Yogyakarta 55283, Indonesia. Tel. 486733, Fax. 486400 \\ Email: soejiantoeko8@ gmail.com*, khansahz1698@gmail.com ${ }^{* *}$, sucinurhidayah9@gmail.com $^{* * *}$
}

\begin{abstract}
Currently, renewable energy can only support 5\% of national energy needs. Meanwhile, in 2035 renewable energy targeted to sustain $14 \%$ of total national energy demand. The proper way for optimizing the renewable energy is needed to actualize the target. Tidal energy as one of the potentials that are still being developed and need more attention from the government. Tidal can be used for natural energy resource since it has zero emission, produce big energy, and has no impact to weather. Larantuka Strait located in Flores island, Nusa Tenggara Timur province can produce tidal velocity up to $2.859 \mathrm{~m} / \mathrm{s}$ with water density as much as $1.025 \mathrm{gr} / \mathrm{cc}$. In utilizing this energy, we use new innovation by using dual tidal turbines which placed at the foot of Palmerah Bridge. The construction of Palmerah Bridge is built both by the government of Flores Island and Adonara Island. Dual tidal turbines are more efficient than single turbine by reason of tidal that has passed through the first turbine can be used again for the second turbine. The using of the generator is meant to convert kinetic energy that produced by dual tidal turbines. To convert ocean currents into electrical energy optimally, it is necessary to plan turbine designs that are in accordance with the conditions of ocean currents and the surrounding environment such as current velocity, wind influences and so on. Horizontal-axis tidal turbine (HATTs) is one of the technologies that are being developed and tested in prototype form by several companies, an efficient blade design is very important for the success of the HATTs. The amount of turbine needs, in this case, is 15 turbines with each turbine's length is 10 meters. The turbines installed in bridge's column along 800 meters. Estimate electricity can be generated by the turbine is 1.48 Mega Watt (MW).
\end{abstract}

Keywords: Dual tidal turbin, Selat larantuka, Tidal energy

Abbreviations: MW (Mega Watt), gr/cc (gram per cubic centimeter), m/s (meter per second), PLTAL (Pembangkit Listrik Tenaga Arus Laut), BPPT (Badan Pengkajian dan Penerapan Teknologi), PSU (Practical Salinity Units)

\section{INTRODUCTION}

It cannot be denied that energy is very important for human life. Almost all human activities need energy in the form of heat, electricity, wind, and other types of energy. National energy needs are increasing every year directly proportional to increasing population. The use of fossil energy cannot be relied on to meet national energy needs because the amount of energy reserves is depleting. In addition to the issue of reserves, fossil energy utilization also raises various problems such as air pollution and global warming which are currently being intensified to be minimized.

New renewable energy is the good solution because besides being renewable, this energy is also considered more environmentally friendly than fossil energy. But in reality, currently renewable energy has not been used optimally so that it can only support $5 \%$ of the total national energy needs. Therefore, the government plans in 2035 to increase the role of renewable energy as a solution to sustain energy needs until $14 \%$ of the total national energy needs. To help realize this plan, the utilization of ocean current energy which has not been optimized so far is considered as a very appropriate action. Ocean current energy is a potential natural resource because it has no gas emissions, is capable of producing large amounts of energy, and is not too affected by weather such as solar and wind energy.
One area with large oceanic energy potential is the tarantula strait located on Flores island, Nusa Tenggara Timur. Flores island is considered the most appropriate place to develop ocean current energy in Indonesia due to several factors. The first factor, based on the performance report of the directorate general of electricity in 2017, NTT is the second area that has the lowest electrification ratio in Indonesia, so it needs an effort to add new energy sources to increase its electrification ratio. The second factor, in this area there is the Larantuka strait which has the largest ocean currents $2,859 \mathrm{~m} / \mathrm{s}$ which is very potential to be utilized. The third factor, in the strait, will be built palmerah bridge which connects adonara island and flores island so that it can be used as a place to install tidal turbine. Using energy from ocean currents in the Larantuka Strait area is expected to target the government plan in 2035 to make the renewable energy into sustaining energy $14 \%$ of national needs can be realized.

\section{MATERIALS AND METHODS}

\section{Methodology}

Methodology used in this research is based on literature such as books, journals, and papers. Analyzing the data can process both qualitative and quantitative. 
Qualitative method used when explaining the potential of tidal energy in Larantuka Strait and the work mechanism of dual tidal turbine. Meanwhile, quantitative method used to present data which support the statement that dual tidal turbine can convert tidal energy into kinetic energy, can calculate electric that generated by tidal energy and calculate the electricity.

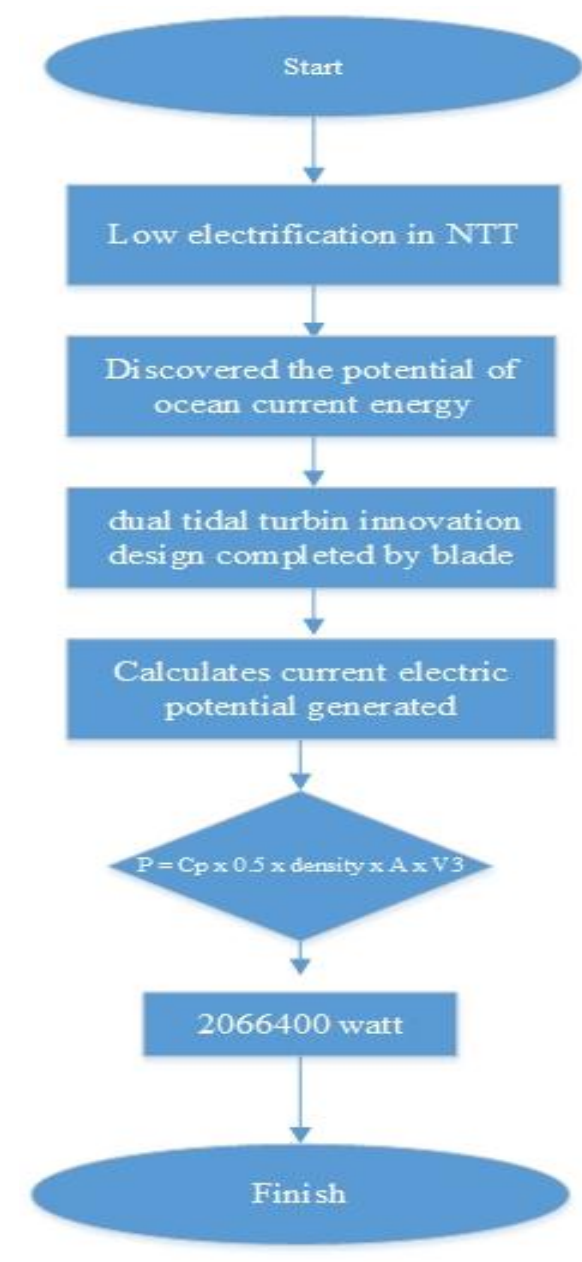

Figure 1. Flow chart.

\section{Tidal Energy}

Indonesia as an archipelago country with marine area up to $6,1 \mathrm{~km}^{2}$. Made Indonesia has bigger opportunity to develop energy based on tidal. Tidal is water mass movement which freed by wine on the surface at depth last than $200 \mathrm{~m}$ (Rahma Widyastuti, 2010). Tidal is one of the essential factor in marine dynamic that give impact to the coast and sea biologically, physically and chemistry in the space and time with the ocean (Dwi Haryanto Ismunarti, 2013).

\section{Concept of Ocean Current Energy}

Basically, ocean currents are horizontal movements of seawater mass which if on a large scale has the potential to be an alternative energy source to replace fossil fuels. The principle used is to convert ocean currents into kinetic energy, then the kinetic energy of these ocean currents will drive turbine power plants. The characteristics of ocean currents are stable and predictable so that they are interesting to develop (Ali Dhiri Fahrudin, 2012).

The concept of the technology of developing ocean current energy adopts wind energy technology that was developed first, which converts kinetic energy into electrical energy. Electrical energy from ocean currents will be greater than wind because the density of seawater is 800 times greater than wind density. As is well known, many countries in the world have succeeded in utilizing the energy of ocean currents into electrical energy such as Scotland, Sweden, France, Norway, England, Northern Ireland, Australia, Italy, South Korea, and the United States.

\section{Characteristics of Larantuka Strait}

The Larantuka Strait which is located in Flores island in Nusa Tenggara Timur has the potential of ocean tidal energy. It is because the tidal energy velocity in the area can reach $2.859 \mathrm{~m} / \mathrm{s}$ with the water density is 1025 $\mathrm{kg} / \mathrm{m} 3$. The potential of ocean tidal energy in the Larantuka Strait is known as the potential resource to be developed into electrical energy. The velocity of ocean tidal energy at the Larantuka Strait towards Flores island reached $2,859 \mathrm{~m} / \mathrm{s}$ which was considered to save the big amount of kinetic energy and potential as a source of electricity.

Table 1. Characteristic of Larantuka Strait.

\begin{tabular}{lll}
\hline No. & Parameter & Characteristic \\
\hline 1. & Density & $1025 \mathrm{~kg} / \mathrm{m}^{3}$ \\
2. & Water depth & $70-100 \mathrm{~m}$ \\
3. & Length of strait & $2.6 \mathrm{~km}$ \\
4. & Current velocity & $1.377-2.589 \mathrm{~m} / \mathrm{s}$ \\
5. & Salinity & $33,86 \mathrm{PSU}$ \\
6. & Temperature & $27,62 \pm 0,14^{\circ} \mathrm{C}$ \\
\hline
\end{tabular}

Table 2. Current velocity of Larantuka Strait.

\begin{tabular}{lllll}
\hline Layer & Stasiun I & \multicolumn{3}{l}{ Stasiun II } \\
\cline { 2 - 5 } & $\begin{array}{l}\text { Current } \\
\text { Velocity } \\
(\mathbf{m} / \mathbf{s})\end{array}$ & $\begin{array}{l}\text { Current } \\
\text { Direction }\end{array}$ & $\begin{array}{l}\text { Current } \\
\text { Velocity } \\
(\mathbf{m} / \mathbf{s})\end{array}$ & $\begin{array}{l}\text { Current } \\
\text { Direction }\end{array}$ \\
\hline 1 & 1,377 & $39,2(\mathrm{U}-\mathrm{TL})$ & 1,895 & $11,3(\mathrm{U}-\mathrm{TL})$ \\
2 & 1,488 & $24,2(\mathrm{U}-\mathrm{TL})$ & 2,147 & $12,8(\mathrm{U}-\mathrm{TL})$ \\
3 & 1,562 & $22,5(\mathrm{U}-\mathrm{TL})$ & 2,432 & $13,2(\mathrm{U}-\mathrm{TL})$ \\
4 & 1,591 & $22,4(\mathrm{U}-\mathrm{TL})$ & 2,464 & $13,6(\mathrm{U}-\mathrm{TL})$ \\
5 & 1,699 & $23,3(\mathrm{U}-\mathrm{TL})$ & 2,495 & $12,1(\mathrm{U}-\mathrm{TL})$ \\
6 & 1,776 & $25,6(\mathrm{U}-\mathrm{TL})$ & 2,607 & $13,8(\mathrm{U}-\mathrm{TL})$ \\
7 & 1,891 & $25,5(\mathrm{U}-\mathrm{TL})$ & 2,753 & $14,2(\mathrm{U}-\mathrm{TL})$ \\
8 & 1,943 & $24,3(\mathrm{U}-\mathrm{TL})$ & 2,807 & $12,5(\mathrm{U}-\mathrm{TL})$ \\
9 & 1,802 & $25,2(\mathrm{U}-\mathrm{TL})$ & 2,828 & $12,3(\mathrm{U}-\mathrm{TL})$ \\
10 & 1,903 & $30,1(\mathrm{U}-\mathrm{TL})$ & 2,859 & $13(\mathrm{U}-\mathrm{TL})$ \\
Layer & 1,667 & $32(\mathrm{U}-\mathrm{TL})$ & 2,381 & $31(\mathrm{U}-\mathrm{TL})$ \\
Average & & & & \\
\hline
\end{tabular}

Based on research that has been carried out by the Engineer Team of the Indonesian Hydrodynamic Laboratory Technical Implementation Unit (UPT LHI) 
BPPT began testing the prototype of the Sea Flow Power Plant (PLTAL). The turbine installed can produce $2 \mathrm{~kW}$ of electricity with the current velocity of $1.4 \mathrm{~m} / \mathrm{sec}$. The results of the engineering team mapping from the UPT LHI BPPT shows that the potential of the Larantuka Strait's electric power of more than 6000 MW depends on the number of turbines installed.

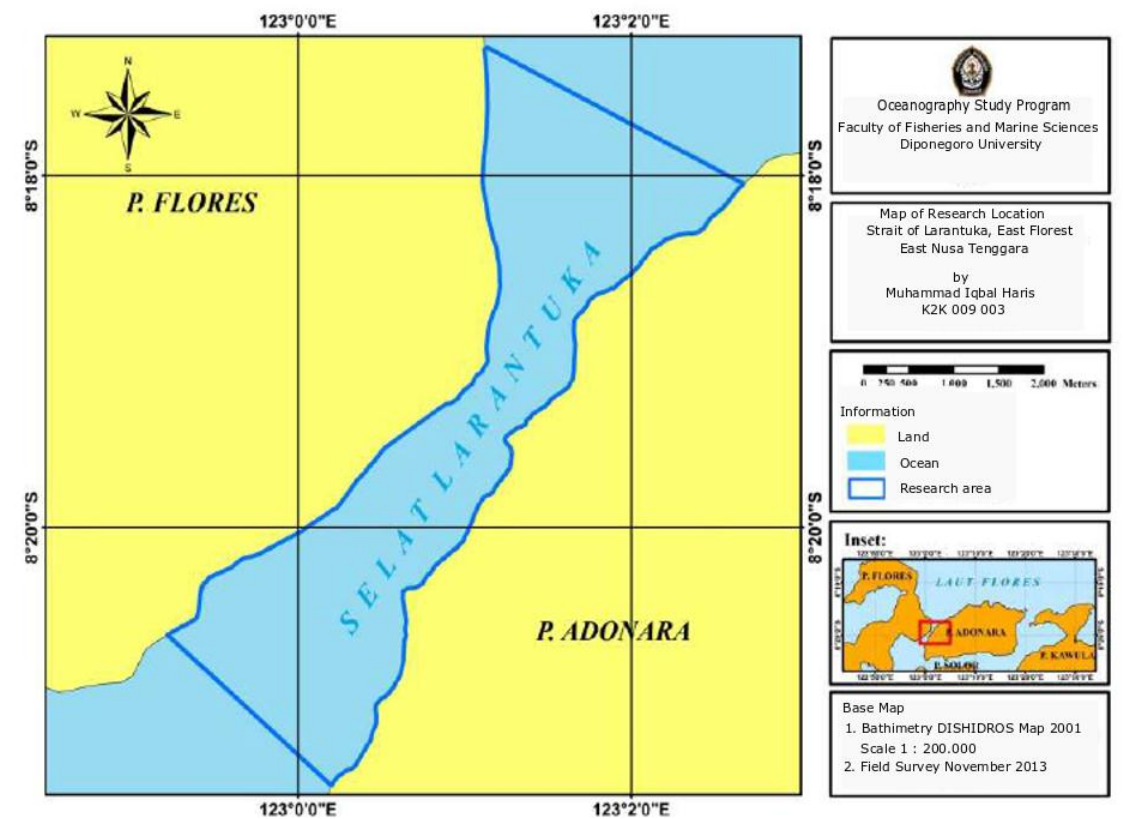

Figure 2. Map of research location (Hendry Syahputr et al., 2014).

\section{Tidal Turbine}

To convert ocean currents into electrical energy optimally, it is necessary to plan turbine designs that are in accordance with the conditions of ocean currents and the surrounding environment such as current velocity, wind influences and so on. Horizontal-axis tidal turbine (HATTs) is one of the technologies that are being developed and tested in prototype form by several companies such as Marine Current Turbine, Verdant Power, and OpenHydro.

Tidal turbine which is meant in the discussion of this paper is the tidal turbine type Horizontal-axis tidal turbine (HATTs), Figure 3 shows illustrations of HATTs with different sea depths. HATTs basically work on the same principles as horizontal axis wind turbines. Rotor The HATTs convert the kinetic energy of the tidal current into the mechanical energy shaft and the generator converts this mechanical energy into electricity. The configuration in Figure 3 differs in the type of support structure used for Rotor turbines. Regardless of the configuration used, the blade rotor is a key component that converts electric current energy and determines the overall performance, load, and dynamics of the turbine system. Therefore, an efficient blade design is very important for the success of the HATTs.

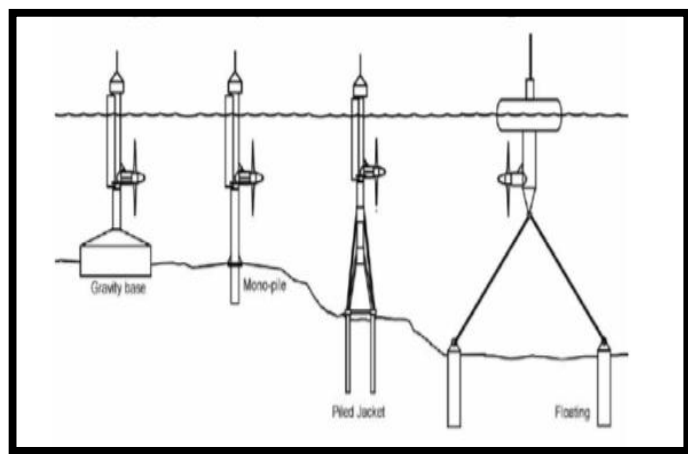

Figure 3. Example of Horizontal-axis tidal turbine (HATTs) configuration based on sea depth (Source: Bir.G.S, and friend. 2011).

\section{Equations}

The output power generated by tidal turbine can be calculated using this equation:

$\mathrm{P}=0.5 \times \rho \times \mathrm{A} \times \mathrm{V}^{3}$

Where :

$A=$ turbine surface area $(\mathrm{m} 2)$

$\rho=$ specific gravity of water $(\mathrm{kg} / \mathrm{m} 3)$

$\mathrm{V}=$ current speed $(\mathrm{m} / \mathrm{s})$

$\mathrm{P}=$ output power (watts)

By assuming that ocean current energy generated has losses in the turbine, the power output equation becomes:

$\mathrm{P}=\mathrm{Cp} \times 0.5 \times \rho \times \mathrm{A} \times \mathrm{V} 3$ 
Where $: \mathrm{Cp}=$ turbine performance constant. Through equation 4.2. with the $\mathrm{Cp}$ is 0.7 , the density is $1025 \mathrm{~kg} / \mathrm{m} 3$, a turbine surface area is $32 \mathrm{~m}^{2}$, a current velocity is $2 \mathrm{~m} / \mathrm{s}$ obtained an output power of 91,840 watts for single tidal turbine utilization. While using dual tidal turbine the output power will be bigger which is 1.5 times bigger, which is 137,760 watts.

Generally, with only using single tidal turbine to convert ocean tidal energy to be mechanical energy. However, the application by single tidal turbine is not optimal because there is still ocean tidal energy generated from one turbine. The design of dual tidal turbine as an innovation that can increase electrical energy generated from electric current. It can be explained from chart 1, the comparison of power generated by Dual tidal Turbine and single tidal turbine, based on the comparison both of turbin is known that the utilization of dual tidal turbine is more optimal than single tidal turbine.

The utilization of dual tidal turbine will be more efficient when combined with a blade airfoil then will increase the electrical power produced. This is because the power of ocean tidal energy passing through the first turbine at the front will be reused to drive the second turbine. The power generated by a single turbine for a current velocity of $2 \mathrm{~m} / \mathrm{s}$ is 91,840 watt, while the power generated with dual tidal turbine for the same current velocity is 137,760 watt.

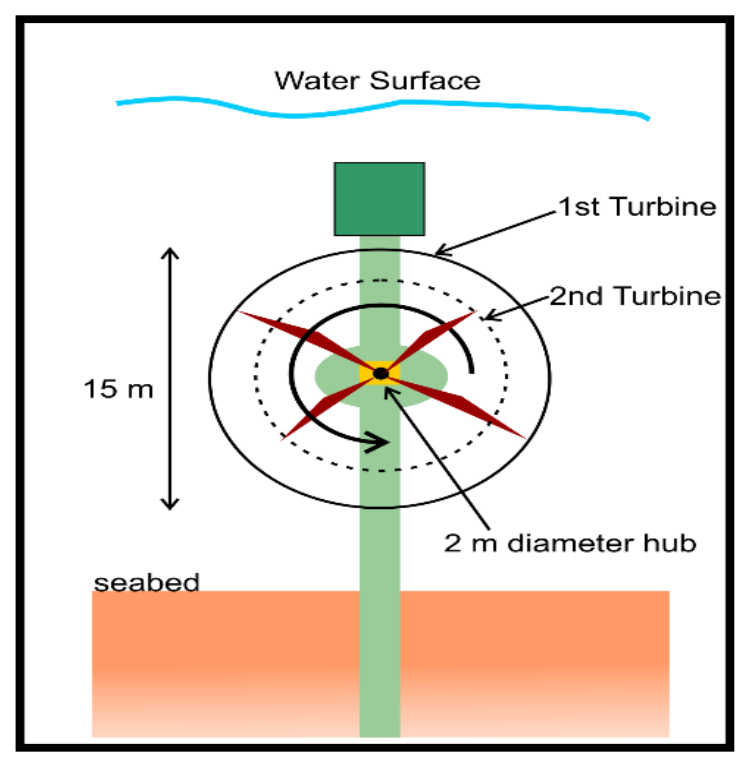

Figure 4. Design of dual tidal turbine.

\section{RESULTS AND DISCUSSION}

\section{Discussion}

Flores is the part of Nusa Tenggara Timur Province and including the island with the second lowest electrification ratio in 2017 which is $59.85 \%$. To solve this problem the utilization of tidal energy is considered very appropriate to applied. It is because in the Flores island there is a Larantuka Strait with the big potency of tidal energy, it is about 1,377-2,859 m/s. In utilizing ocean tidal energy, dual tidal turbine is used to convert kinetic power of ocean currents into mechanical energy then converted into electricity by a generator. The use of dual tidal turbine with blade airfoil is an innovation to utilize ocean tidal energy become more optimally.

Table 3. Specification of dual tidal turbine.

\begin{tabular}{lll}
\hline No. & Specification & Information \\
\hline 1. & Amount of Rotor & 1 \\
2. & Rotor diameter & $15 \mathrm{~m}$ \\
3. & Hub diameter & $2 \mathrm{~m}$ \\
4. & Maximum speed of Rotor & $11,5 \mathrm{rpm}$ \\
5. & Average Velocity & $1,377-2,859 \mathrm{~m} / \mathrm{s}$ \\
6. & Primary blade airfoil & NACA $63 \mathrm{i}-424$ \\
7. & Surface area of Turbine & $32 \mathrm{~m}^{2}$ \\
8. & Cp & 0,7 \\
\hline
\end{tabular}

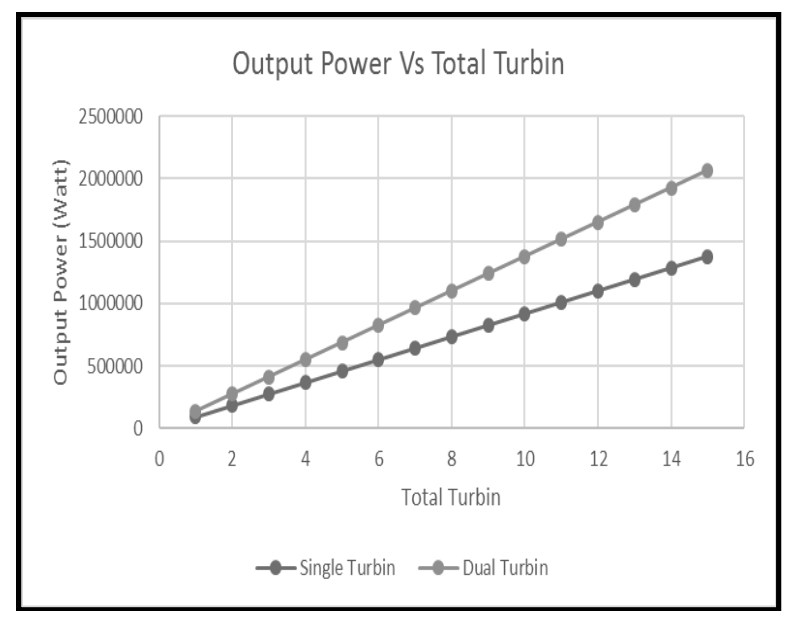

Figure 5. Power generated by single tidal turbine and dual tidal turbine.

This is because the ocean tidal energy that pass through the turbine is still can be reused to drive the two turbines. The dual tidal turbine will be installed at the foot of the Palmerah Bridge to be built on the Larantuka Strait to link the Flores island to Adonara island. The plan will be installed 15 dual tidal turbines at the foot of the bridge. Tidal turbine with a length of each turbine is $15 \mathrm{~m}$, the surface area is $32 \mathrm{~m}^{2}$, and Cp is 0.7 , seawater density is $1025 \mathrm{~kg} / \mathrm{m} 3$ and the velocity of the current is $2 \mathrm{~m} / \mathrm{s}$ and will get an output power in the amount of 2,066,400 watts (2.06 MW). From the output power produced, it can be used to generate electricity for 4592 houses, the increasing of electrification ratio become $60.253 \%$ or increase in the amount of $0.403 \%$. The increasing of electrification ratio is large because the increased electrification ratio influences one NTT province. With the increase in the electrification ratio generated from the utilization of tidal energy, it is expected to be able to help the government's plan to make the renewable energy sector sustain $14 \%$ of national needs by 2035 . 


\section{CONCLUSIONS}

1. The usage of dual tidal turbine is more optimal than single turbine

2. Output power generated by 15 dual tidal turbine is 2.066.400 watt $(2,06 \mathrm{mw})$

3. Tidal energy utilization will increase the ratio of electrification in NTT about $0,403 \%$.

\section{ACKNOWLEDGMENTS}

We would like to express our appreciation to Mrs. Kristiati for some experiment advices. Also we would like to acknowledgment Mr. Allen for the support and we don't forget to extend it to some lab assistants for the help given.

\section{REFERENCES}

Azis, Asruldin. 2009. Studi Pemanfaatan Energi Listrik Tenaga Arus Laut di Selat Alas Kabupaten Lombok, NTB. Surabaya: Institut Teknologi Sepuluh November.

Barbarelli, Silvio, and friends. 2016. Design and Numerical Analysis of A Double Rotor Turbine Prototype Operating in Tidal
Currents. Conference of the Italian Thermal Machines Engineering Association. Calabria, Italia.

Bir.G.S, and friend. 2011. Structural Design of A Horizontal-axis Tidal Current Turbine Composite Blade. Conference on Ocean, Offshore, and Arctic Engineering. Rotterdam, The Netherlands.

Fahrudin Ali Dhikri,dkk. 2012. Implementasi Pengembangan Energi Arus Laut dalam Pengembangan Wilayah (Studi Kasus Kawasan Pesisir Flores Timur,NTT). Institut Teknologi Sepuluh November.

Havis, Muhammad Iqbal. 2014. Kajian Batimetri dan Pasang Surut dalam Menentukan Lokasi Instalasi Turbine Pembangkit Listrik Tenaga Arus Laut di Selat Larantuka,Flores Timur,

Ismunarti, Dwi Haryo. 2013. Kajian Arus di Perairan Nusa Tenggera Barat dan Simulasinya Menggunakan Pendekatan Model Matematik. Buletin Oceanografi Marina Januari 2014. Volume 2. Halaman 1-11.

Kasharjanto, Afian, dkk. 2017. Uji Kinerja Turbine Pembangkit Listrik Arus Laut Lambung Ganda 10 Kilowatt di Jembatan Suramadu. Jurnal Ilmu Pengetahuan \& Teknologi Kelautan. Volume. 14. Hal 79-86.

Nusa Tenggara Timur. Jurnal Oseanografi,Volume 3,Nomor 4, Halaman 486-492.

Syahputra, Henry, dkk. 2014. Kajian Potensi Arus Laut sebagai Energi Pembangkit Listrik di Selat Larantuka, Flores Timur, Nusa Tenggara Timur. Buletin Oceanografi Marina Januari 2014. Volume 3. Halaman 1-8.

Widyastuti, Rahma,dkk. 2010. Pemodelan Pola Arus Laut Permukaan di Perairan Indonesia Menggunakan Data Satelit Altimetri Jason-1. Institut Teknologi Sepuluh November. 
THIIS PAGE INTENTIONALLY LEFT BLANK 